\title{
The Impact of Canyon Design on the Thermal Environment of the Coastal Area of Selatpanjang City
}

\author{
Rahman, B. \\ Post Graduate \\ Department of Architecture \\ Institut Teknologi Sepuluh Nopember \\ Surabaya, Indonesia
}

\author{
Defiana, I. \\ Lecturer \\ Department of Architecture \\ Institut Teknologi Sepuluh Nopember \\ Surabaya, Indonesia
}

\author{
Dinapradipta, A. \\ Lecturer \\ Department of Architecture \\ Institut Teknologi Sepuluh Nopember \\ Surabaya, Indonesia
}

\begin{abstract}
Increasing numbers of building floors in Selatpanjang city provides a double surface for the process of sunlight reflection and air flow barrier on the building canyon environment. Meanwhile, cooling by airflow is highly required along with changes in the physical city which potentially lead to the formation of Urban Heat Islands (UHI). The presence of a link between buildings to the thermal environment performance leads to the need of a study on canyon designs in the different conditions that is affected conditions by the waterfront building barrier. This study is an experimental research conducted using ENVI-met V3.1 software simulation. Canyon design with low $\mathrm{H} / \mathrm{W}$ value (1.05 and 0.9$)$ produces air temperature of $34.7^{\circ} \mathrm{C}$ and $35.4^{\circ} \mathrm{C}$. There is a difference of $1-2.4^{\circ} \mathrm{C}$ higher than canyon design with high $\mathrm{H} / \mathrm{W}$ value. Condition of the implementation of the regulation of Directorate General of Human Settlements (2000), shallow canyon (H/W low) still produces higher air temperature values than the deep canyon $(\mathrm{H} / \mathrm{W}$ high) but with a small value difference of $0.1^{\circ} \mathrm{C}-0.37^{\circ} \mathrm{C}$. Long canyon resulted in lower airflow velocity value changes when compared to short canyon at all altitude levels of $0.78-0.87 \mathrm{~m} / \mathrm{s}$ versus $1.3-1.46 \mathrm{~m} / \mathrm{s}$. with the result that providing a better cooling effect.
\end{abstract}

Keywords-Thermal Environment; Coastal City Area; Urban Canyon Design, Airflow Velocity.

\section{INTRODUCTION}

In the last few years, along with societal development and dynamics, Selatpanjang City has undergone an increase in regional function. Initially only functioning as a settlement, however due to the rapid growth of several urban areas, the regional function has grown to include trade services, offices and also industries- to name a few. This condition has led to the emergence of new buildings with different heights that resulted in changes in the geometric design of building canyons. The changes that occured in the design of the building canyons have the effect of not bearing enough space for heat release conducted through the airflow between. Meanwhile, cooling by airflow is highly required along with changes in the physical city which potentially lead to the formation of Urban Heat Islands (UHI), which is the condition of increased temperature in central urban areas [1].
Based on the explanation above, this study evaluates the thermal environmental performance in the current condition of Selatpanjang City and analyzes the influence of the urban canyon design models on the thermal environment in the different conditions that is affected conditions by the waterfront building barrier. This is related to the regulation of the Directorate General of Human Settlements [2] on spatial and building planning in waterfront areas (fig 1).

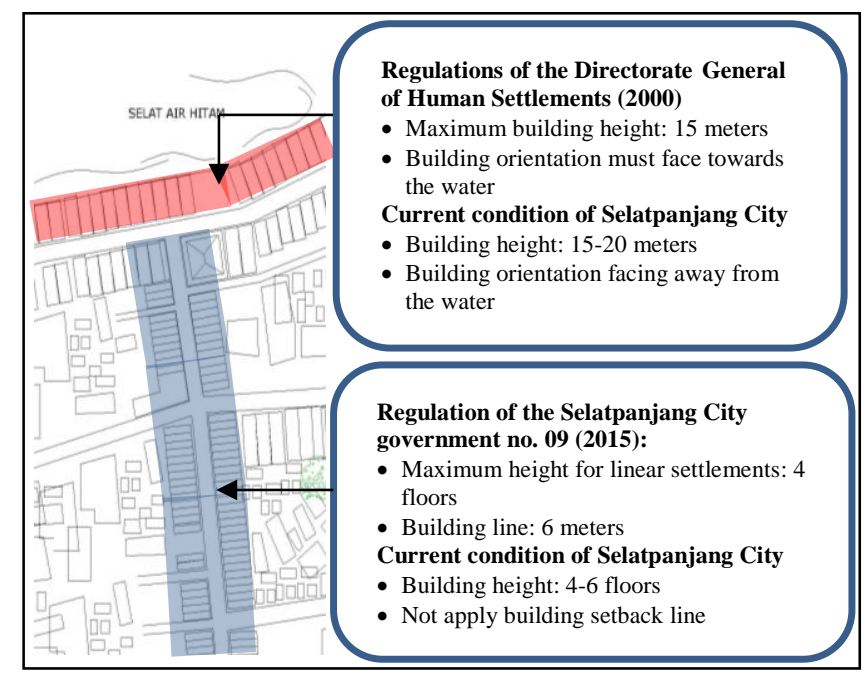

Fig. 1. Condition of canyon design of Selatpanjang city

\section{THEORETICAL REVIEW}

In urban environments, the microclimate is influenced by urban space design, urban surfaces and the level of anthropogenic activity causing significant increases in air temperature (Ta) and surface temperature (Ts), depending on the city size and local climatic characteristics [3]. One form of urban space design arising from the growth of the city is the formation of canyons. A canyon is a linear space between buildings standing on two sides and the performance of the thermal environment in the canyon is influenced by the aspect ratio of the building height $(\mathrm{H})$ to the road width $(\mathrm{W})$ [4]. There are two characteristic forms of canyon design, namely 
deep canyon and shallow canyon [5]. Deep canyon characterizes urban areas with high density, whereas shallow canyon represents urban areas with low density (fig 2). Deep canyon design has a cooling effect, while shallow canyon design creates a very uncomfortable environment. Significant temperature increments in shallow canyons are caused by high solar radiation exposure on the urban road surface [6]. Hang, et al. [7] evaluated several types of canyon lengths, namely $\mathrm{L} 47.4$, L 79, $\mathrm{L} 333$. The reduction of airflow velocity in L 47.4 was smaller compared to L 79 and L 333. This indicates that longer canyons result in lower airflow velocity changes at the pedestrian level.

Oke, et al. [8] Comparison of building height $(\mathrm{H})$ to the road width $(\mathrm{W})$ produces an influence on heat mitigation. Buildings with different heights maintain radiation emitted so that the heat is then trapped within the urban canyon that causes the urban environment to become hotter. Aynsley [9] explained that the airflow movement in the external environment is influenced by the presence of barriers such as buildings and vegetation composed due to the combination of form, altitude and distance in certain site characters. Boutet [10] Configuration of buildings in the form of orientation, altitude, overhangs, and the shape of the roof may cause deflection and changes in airflow velocity in the environment. A comparison of buildings with similar lengths and widths, but having different heights, results in eddy flow and longer calm area zone. This is influenced by the airflow jump that occurs over the top of the building, so that the airflow requires a longer distance to return to its normal stream [11].

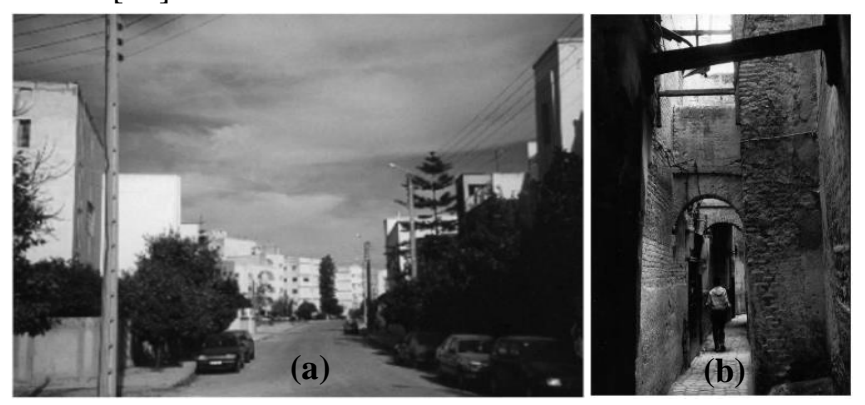

Fig. 2. : Types of canyon design: a) shallow canyon; b) deep canyon [5]

III. METHOD

This experimental research uses ENVI-met V3.1 software simulation. Environmental and building aspects identified are: 1) Built up area as defined by Building Setback Line (BSL) and Number-of-Floors (NOF); 2) Geometric design of the building canyon as defined by the aspect ratio of the building height to the road width $(\mathrm{H} / \mathrm{W})$ and the canyon length to the building height $(\mathrm{L} / \mathrm{H})$.

\section{A. Research sample and population}

The research population is the western region of Selatpanjang City. The research radius ranges $350 \mathrm{~m}^{2}$. Further, the urban canyon studied is one of the three main urban roads namely Imam Bonjol Road (fig 3). The choice of the road considers the height and density of activities occurring in the road environment.

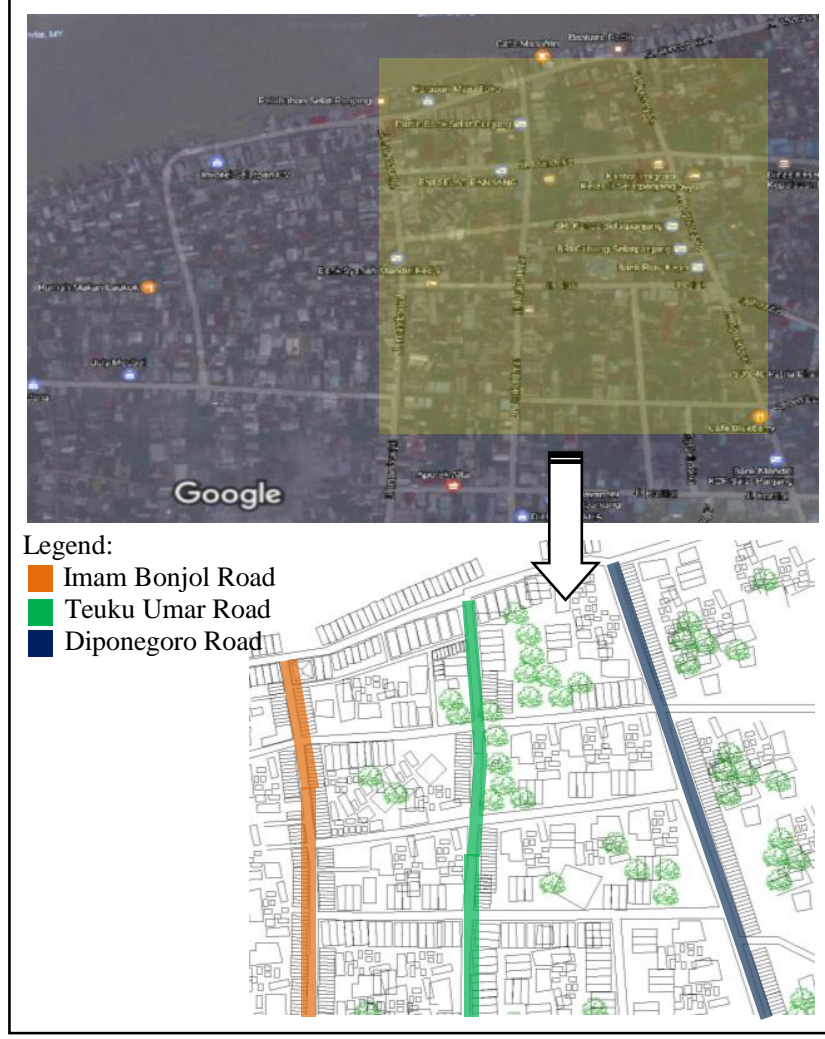

Fig. 3. Research sample and population

\section{B. Field measurement}

Field measurement begins from the location of the canyon closest to the edge of the water, and continues towards the center over a radius of $350 \mathrm{~m}$. Four (4) measurement points are determined based on the crossings which divide the length of the canyon design [12]. Each measurement point is named canyon 1, 2, 3, and 4 (fig 4). Measurement of temperature, humidity and airflow velocity are carried out simultaneously in each point at an altitude of 1.5- $1.75 \mathrm{~m}$ above the road surface [13]. In airflow velocity measurement, an additional point is added at the coastal area (no barriers) to record the airflow velocity at maximum condition. Recording of measurements are done every 2 hours starting at 08.00 (GMT+7) until 24.00 (GMT+7).

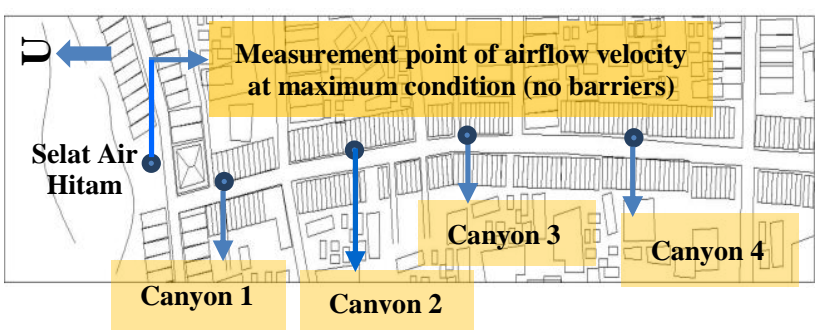

Fig. 4. Four measurement points on Imam Bonjol Road

\section{Experiment design}

The experimental model is divided into 3 scenarios with one of the scenario reference to regulations set by the Directorate General of Human Settlements [2]. Further, the impact on thermal environment performance on 6 variations of canyon building design models are modified through aspect ratio of the building height to the road width $(\mathrm{H} / \mathrm{W})$ 
reference to local government regulations of Selatpanjang City [14] about Building Setback Line (BSL) and Numberof-Floors (NOF) (Table 1, 2).

TABLE 1. EXPERIMENT DESIGN MODEL SCENARIOS

\begin{tabular}{|c|c|c|c|c|c|}
\hline \multirow{2}{*}{\multicolumn{2}{|c|}{ Scenario }} & \multirow[t]{2}{*}{ Model } & \multicolumn{2}{|c|}{$\begin{array}{c}\text { Urban Canyon } \\
\text { Geometry }\end{array}$} & \multirow{2}{*}{$\begin{array}{l}\text { Model } \\
\text { code }\end{array}$} \\
\hline & & & $H / W$ & $L / H$ & \\
\hline \multirow{6}{*}{1} & \multirow{6}{*}{$\begin{array}{l}\text { No coastal barrier } \\
\text { buildings } \\
\text { (Directorate General } \\
\text { of Human } \\
\text { Settlements, 2015) }\end{array}$} & A & 0.78 & 7.88 & $1 \mathrm{~A}$ \\
\hline & & B & 0.38 & 16.22 & $1 B$ \\
\hline & & C & 1.29 & 16.22 & $1 C$ \\
\hline & & D & 2.06 & 7.88 & 1D \\
\hline & & $\mathrm{E}$ & 0.49 & 16.22 & $1 \mathrm{E}$ \\
\hline & & $\mathrm{F}$ & 1.02 & 7.88 & $1 \mathrm{~F}$ \\
\hline \multirow{6}{*}{2} & \multirow{6}{*}{$\begin{array}{l}\text { With coastal barrier } \\
\text { buildings NOF } 2 \text { ( } 7 \\
\text { meters) }\end{array}$} & A & 0.78 & 7.88 & $2 \mathrm{~A}$ \\
\hline & & B & 0.38 & 16.22 & $2 \mathrm{~B}$ \\
\hline & & C & 1.29 & 16.22 & $2 C$ \\
\hline & & D & 2.06 & 7.88 & $2 \mathrm{D}$ \\
\hline & & $\mathrm{E}$ & 0.49 & 16.22 & $2 \mathrm{E}$ \\
\hline & & $\mathrm{F}$ & 1.02 & 7.88 & $2 \mathrm{~F}$ \\
\hline \multirow{6}{*}{3} & \multirow{6}{*}{$\begin{array}{l}\text { With coastal barrier } \\
\text { buildings NOF } 4 \text { (15 } \\
\text { meters) }\end{array}$} & A & 0.78 & 7.88 & $3 \mathrm{~A}$ \\
\hline & & B & 0.38 & 16.22 & $3 B$ \\
\hline & & C & 1.29 & 16.22 & $3 C$ \\
\hline & & D & 2.06 & 7.88 & $3 \mathrm{D}$ \\
\hline & & $\mathrm{E}$ & 0.49 & 16.22 & $3 \mathrm{E}$ \\
\hline & & $\mathrm{F}$ & 1.02 & 7.88 & $3 F$ \\
\hline
\end{tabular}

TABLE 2. MODEL DESCRIPTION

\begin{tabular}{|l|l|l|l|}
\hline $\begin{array}{l}\text { Model } \\
\text { code }\end{array}$ & Model treatment & Description \\
\hline & & $\begin{array}{l}\text { BSL: 6 meters } \\
\text { Road width: 5 meters } \\
\text { NOF: 4 (15 meters) }\end{array}$ \\
\hline C & & & \\
\hline
\end{tabular}

\section{RESULTS}

\section{A. Field study}

Canyon designs 3 and 4 have a type shallow canyon with lower $\mathrm{H} / \mathrm{W}$ values but do not produce lower air temperatures than canyon designs 1 and 2 . The air temperature values in canyon designs 3 and 4 at extreme time $(14: 00)$ are $34.7^{\circ} \mathrm{C}$ and $35.4^{\circ} \mathrm{C}$, respectively, while in canyon designs 1 and 2 the temperature is $34^{\circ} \mathrm{C}$ (fig. 5).

In accordance with the above temperature conditions, air humidity conditions, which is affected by low airflow velocity and high air temperature experience a decrease in value of 46-50\% occurring at 14.00 (extreme time), with canyon design 2 having the highest value of $49.2 \%$ (fig 6).

In airflow velocity conditions, the decrease that occurs between the inlet position and within the canyon building design is impacted by coastal barrier buildings. At the inlet position, the airflow velocity has an average value of 2.5-3.5 $\mathrm{m} / \mathrm{s}$ and continues to decrease as the radius/ distance from the water edge increases by $0.2-0.8 \mathrm{~m} / \mathrm{s}$ (fig 7).

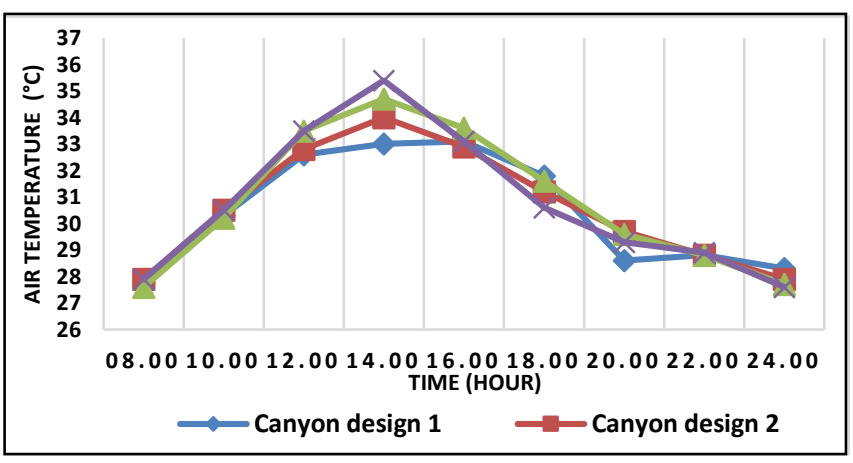

Fig. 5. Graph of air temperature in canyon design

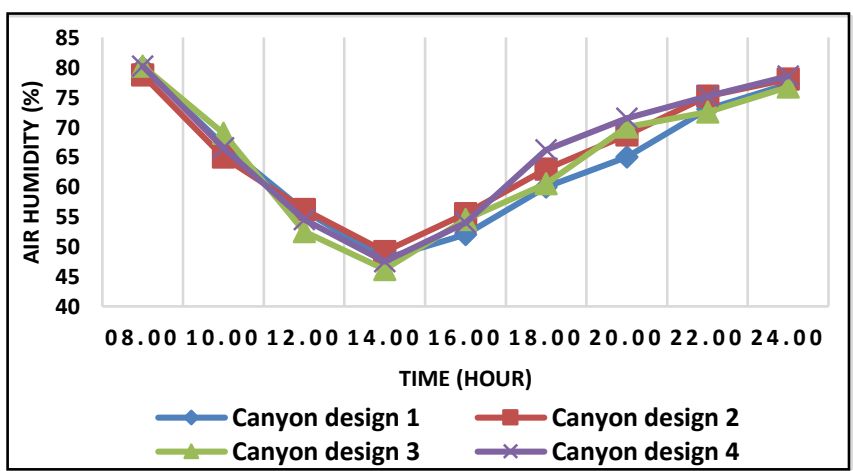

Fig. 6. Graph of air humidity in canyon design

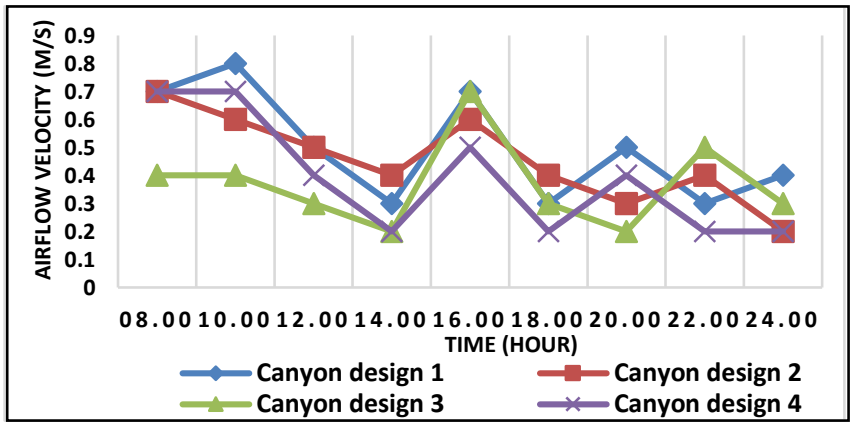

Fig. 7. Graph of airflow velocity in canyon design 
Specifically in this study, the urban configurations which potentially affect thermal environmental performance in the urban canyon design are as follows:

1. Based on aspects of function: tall buildings are generally reserved for shophouses with building height of 5 floors (5-25 meters), while low buildings generally function as residential buildings and places of worship with building height of no more than 1 floor (3-5 meters).

2. Based on aspects of configuration: maximum $\mathrm{H} / \mathrm{W}$ value of 2.14 is located on canyon design 1 , followed by canyon design 2 with 1.72 , canyon design 3 with 1.05 , and canyon design 4 with 0.90 . For $\mathrm{L} / \mathrm{H}$ values, canyon design 1 is determined by a measurement radius of \pm $104 \mathrm{~m}(\mathrm{~L} / \mathrm{H}=9.71)$, canyon design 2 with a measurement radius of \pm $110 \mathrm{~m}(\mathrm{~L} / \mathrm{H}=12.74)$, canyon design 3 with a measurement radius of \pm $78 \mathrm{~m}(\mathrm{~L} / \mathrm{H}=7.39)$, and design canyon 4 with a measurement radius of $\pm 177 \mathrm{~m}(\mathrm{~L} / \mathrm{H}=17.10)$. The buildings mainly have a linear pattern. Most of the buildings are densely lined up in a north-south orientation.

\section{B. Experimental scenario 1}

The lowest air temperature value recorded at extreme time is found in model $1 \mathrm{D}$ with $27.81^{\circ} \mathrm{C}$ and $\mathrm{H} / \mathrm{W}=2.06$. The highest air temperature value is found at model $1 \mathrm{E}$ with $28.28^{\circ} \mathrm{C}$ and $\mathrm{H} / \mathrm{W}=0.49$. Models $1 \mathrm{~A}$ and $1 \mathrm{~B}$ are having a temperature value of $28.13^{\circ} \mathrm{C}(\mathrm{H} / \mathrm{W}=0.78)$ and $28.25^{\circ} \mathrm{C}(\mathrm{H} / \mathrm{W}=0.38)$.

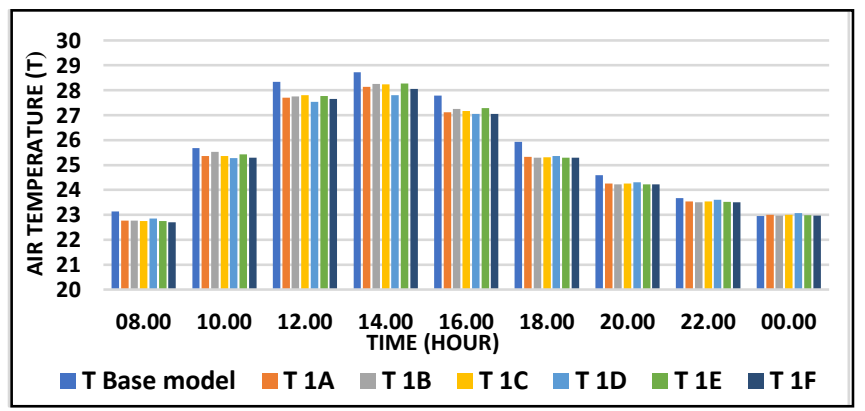

Fig. 8. Comparison of air temperature conditions in scenario 1

Observing the overall experiment model, the comparison of air temperature conditions does not yield highly different results, i.e. $0.25-0.47^{\circ} \mathrm{C}$, with deep canyon having the lowest air temperature values. This shows that deep canyon is to be more preferred than shallow canyon because of its cooling effect $[5,6]$.

On the case of humidity, the highest value is found at model 1D with $63.77 \%$ (fig. 9). The air humidity condition in scenario 1 also does not have a great difference (0.27-0.52\%).

The next climatic element is airflow velocity. The application of the regulation imposed by the Directorate General of Human Settlements [2] in scenario 1 produces a value increment of the airflow velocity in certain canyon deisgn models (fig. 10). The lowest airflow velocity occurs at model 1D with $0.66 \mathrm{~m} / \mathrm{s}$. Canyon designs with the NOF 4 has a lower airflow velocity condition when compared to canyon designs with NOF 2.

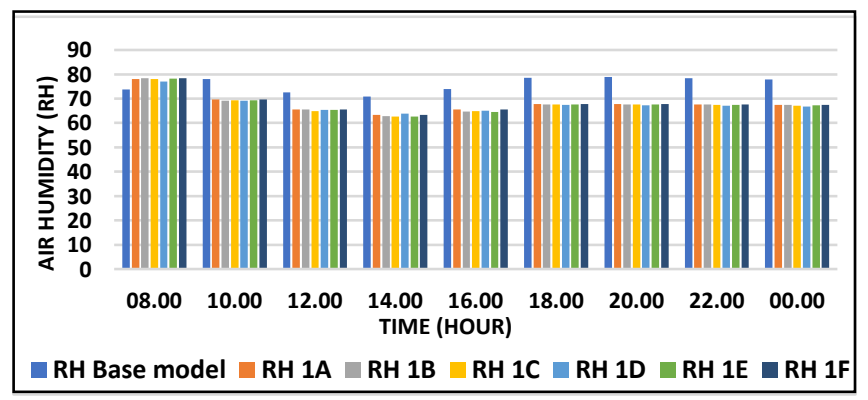

Fig. 9. Comparison of air humidity conditions in scenario 1

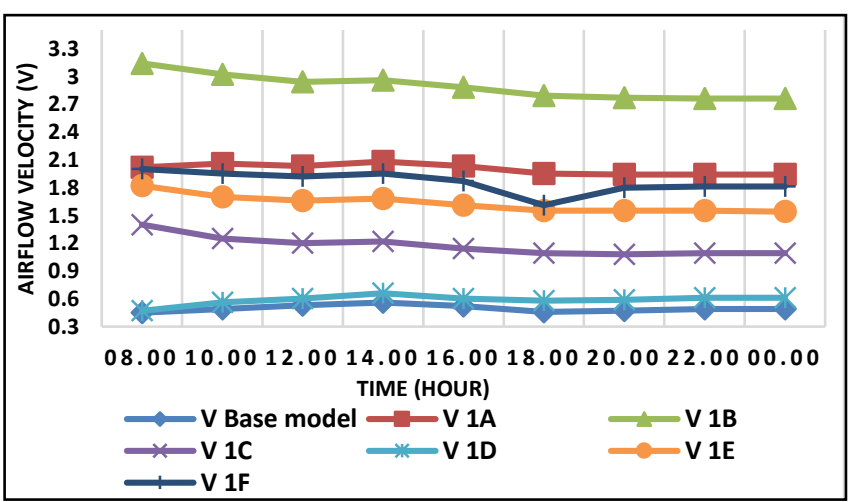

Fig. 10. Comparison of airflow velocity conditions in scenario 1

\section{Experimental scenario 2}

In scenario 2 the airflow velocity experienced changes twice, caused by the existence of barrier buildings which forms a leeward area before entering into the canyon (fig. 11). The airflow velocity in the inlet condition is $2.49-3.73 \mathrm{~m} / \mathrm{s}$.

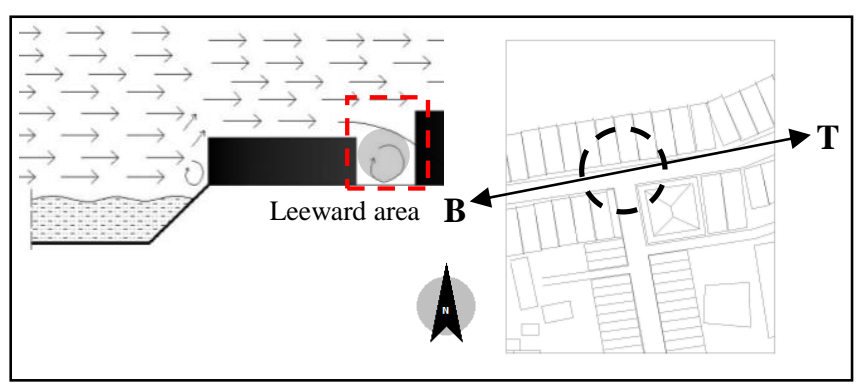

Fig. 11. Barrier buildings create a leeward area in west-east oriented canyon design

The presence of barrier buildings causes changes in air temperature conditions of canyon design 2 when compared to canyon design 1 . Canyon design $2 \mathrm{D}$ becomes the model with the highest temperature value of $28.85^{\circ} \mathrm{C}$ (fig. 12). The lowest air temperature condition occurs at model $2 \mathrm{~F}$ with a value of $28.11^{\circ} \mathrm{C}(\mathrm{H} / \mathrm{W}=1.02)$.

Similar to scenario 1 , the highest air humidity condition is found at the experimental model with the lowest air temperature value which is model $2 \mathrm{~F}$ with the value $65.77 \%$ (fig. 13). The measurement is higher by $2 \%$ than the highest air humidity condition present in the canyon design of scenario 1 . The lowest air humidity condition when observed at extreme time happens at model $2 \mathrm{C}$ of $64.66 \%(\mathrm{H} / \mathrm{W}=$ $1.29)$. Overall changes in air humidity value which occur in scenario 1 and 2 range around $62 \%-66.02 \%$. In scenario 2 , air humidity conditions are higher when compared to conditions in scenario 1 .

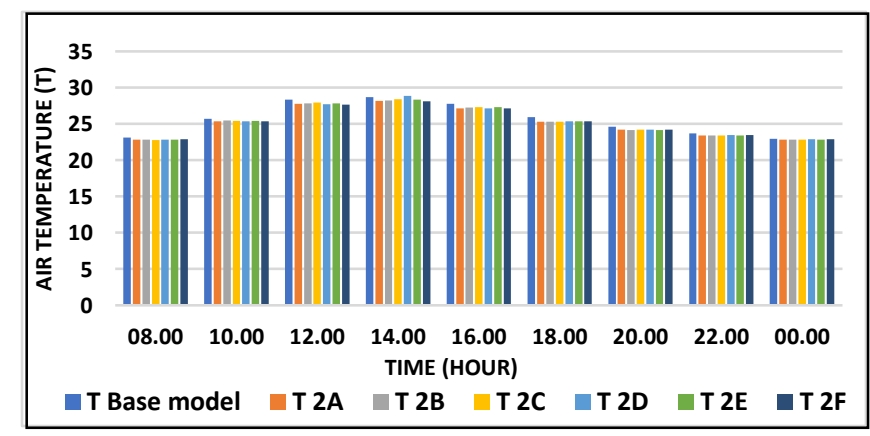

Fig. 12. Comparison of air temperature conditions in scenario 2 


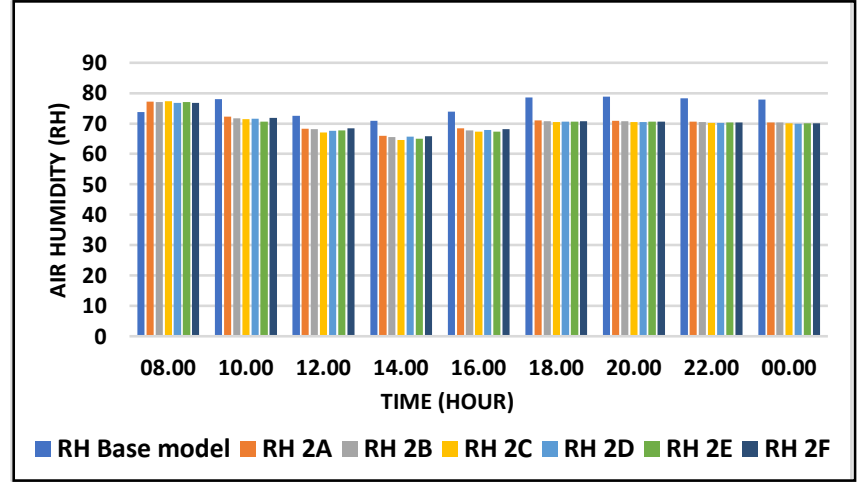

Fig. 13. Comparison of air humidity conditions in scenario 2

Deep canyon (H/W 2.06) with characteristics no BSL and NOF 4 has a lower airflow velocity value. This can be seen in models 2D. Models have an airflow velocity of only 0.5 (fig. 14). The condition where the airflow velocity value is highest occur at models type shallow canyon (H/W 0.38) with characteristics BSL 2 and NOF 2, which are $2 \mathrm{~B}(3,16 \mathrm{~m} / \mathrm{s})$. The difference of airflow velocity between base model is 1.48 $\mathrm{m} / \mathrm{s}$.

\section{Experimental scenario 3}

The airflow velocity value before entering into the canyon is $0.63-1.89 \mathrm{~m} / \mathrm{s}$. The recorded values decrease around $1.5-$ $2 \mathrm{~m} / \mathrm{s}$ when compared to scenario 2 and around $3-3.5 \mathrm{~m} / \mathrm{s}$ when compared to scenario 1 .

The lowest air temperature condition happens at model 3D of $28.63^{\circ} \mathrm{C}$ which only differs by $0.09^{\circ} \mathrm{C}$ to the base model. The highest condition is recorded at model $3 \mathrm{C}$ with $29.14^{\circ} \mathrm{C}$, higher than the base model (fig. 15).

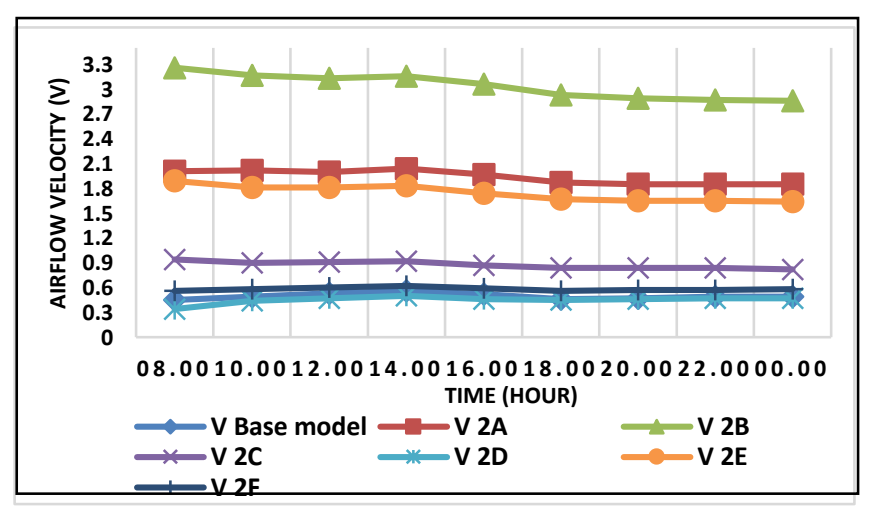

Fig. 14. Comparison of airflow velocity conditions in scenario 2

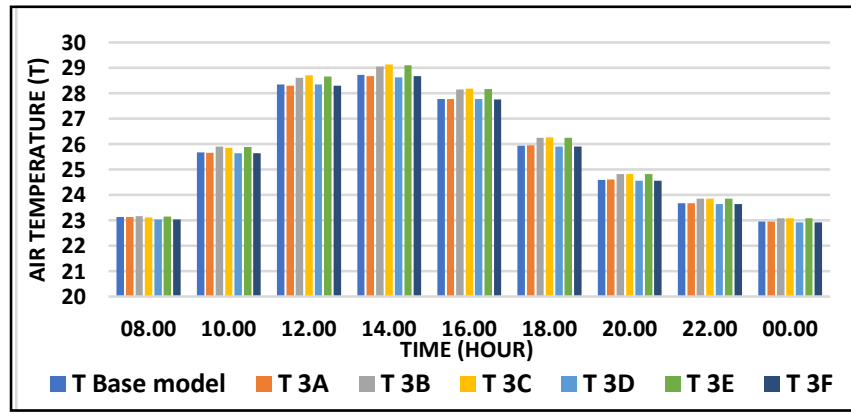

Fig. 15. Comparison of air temperature conditions in scenario 3
In the next thermal profile of air humidity, a steep change is observed when compared to the values shown in scenarios 1 and 2 . The humidity values across all experimental models in scenario 3 average at $70 \%$ (fig. 16). The highest air humidity is present in model $3 \mathrm{~B}$ with a value of $72.78 \%$ and the lowest at model $3 \mathrm{~F}$ with $71.24 \%$. Low air exchanges in the canyon design to decreased airflow velocity resulted in the increase of air humidity in conditions of rising air temperature.

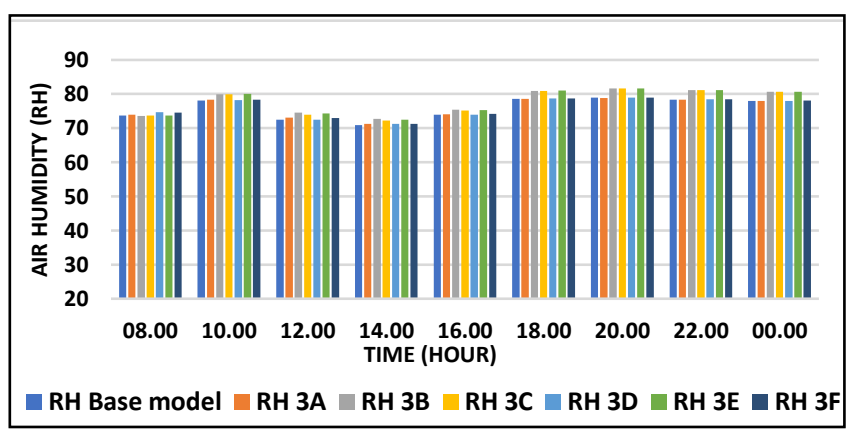

Fig. 16. Comparison of air humidity conditions in scenario 3

Airflow velocity conditions in the experimental models of scenario 3 decrease in value compared to scenarios 1 and 2 . Experimental models with NOF 4 have an airflow velocity condition lower than experimental models with NOF 2. Examples include models $3 \mathrm{~A}, 3 \mathrm{D}$, and $3 \mathrm{~F}$ with the values $1.84 \mathrm{~m} / \mathrm{s}, 0.82 \mathrm{~m} / \mathrm{s}$, and $1.94 \mathrm{~m} / \mathrm{s}$, respectively (fig. 17). The highest condition appears in model 3B $(2.94 \mathrm{~m} / \mathrm{s})$ and while the lowest condition appears in model 3D (0.82). The changes that occur to the airflow velocity in scenarios 2 and 3 are impacted by dimension of barrier buildings $(\mathrm{H})[11,15]$.

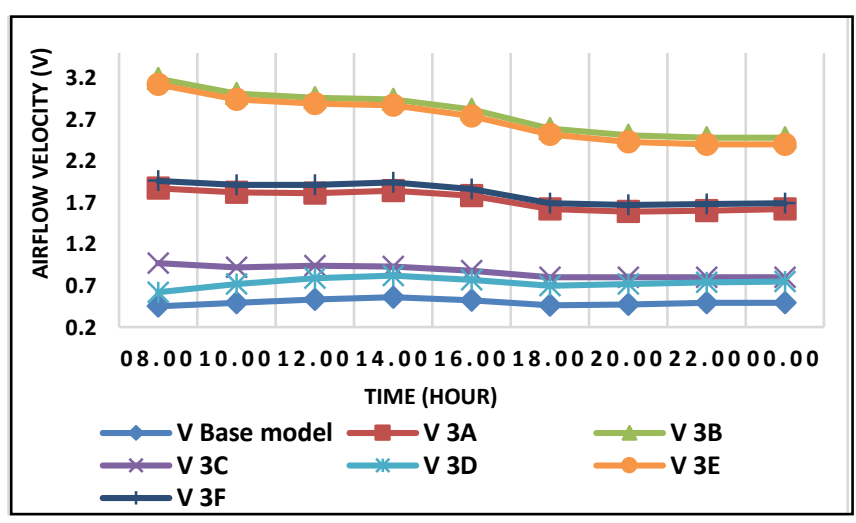

Fig. 17. Comparison of airflow velocity conditions in scenario 3

\section{E. Impact of $L / H$ aspect ratio towards changes in airflow velocity of scenario 1}

Models 1A and 1B experience a great reduction in airflow velocity at the starting point (T1) leading towards the second point (T2) with values of $1.37 \mathrm{~m} / \mathrm{s}$ and $0.82 \mathrm{~m} / \mathrm{s}$, respectively (Table 2). In the next point no steep changes occur in either model 1A or 1B. 1A experiences a decrease of $0.12 \mathrm{~m} / \mathrm{s}-0.74$ $\mathrm{m} / \mathrm{s}$ at pedestrian level, $0.05-0.7 \mathrm{~m} / \mathrm{s}$ at mid-level, and $0.45-$ 0.74 at top level (fig. 18). Meanwhile model 1B experience a decrease around $0.04 \mathrm{~m} / \mathrm{s}-0.27 \mathrm{~m} / \mathrm{s}$ at pedestrian level, $0.06-$ $0.27 \mathrm{~m} / \mathrm{s}$ at mid-level, and $0.14-0.28 \mathrm{~m} / \mathrm{s}$ at top level (fig. 19). 
TABLE 2. CHANGES IN AIRFLOW VELOCITY AT POINT T1MOVING TOWARDS T2 (MODEL 1A DAN 1B)

\begin{tabular}{|c|l|l|}
\hline \multirow{2}{*}{ Level } & Experimental Model \\
\cline { 2 - 3 } & $1 \mathrm{~A}$ & $1 \mathrm{~B}$ \\
\hline Pedestrian & $1.3 \mathrm{~m} / \mathrm{s}$ & $0.87 \mathrm{~m} / \mathrm{s}$ \\
\hline Middle & $1.37 \mathrm{~m} / \mathrm{s}$ & $0.78 \mathrm{~m} / \mathrm{s}$ \\
\hline Top & $1.46 \mathrm{~m} / \mathrm{s}$ & $0.83 \mathrm{~m} / \mathrm{s}$ \\
\hline
\end{tabular}

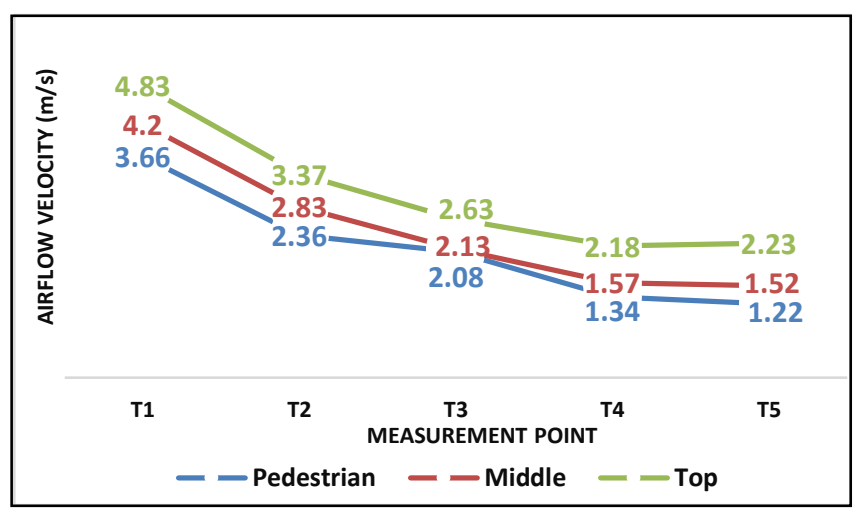

Fig. 18. Graph of airflow velocity reduction in scenario 1 (model 1A)

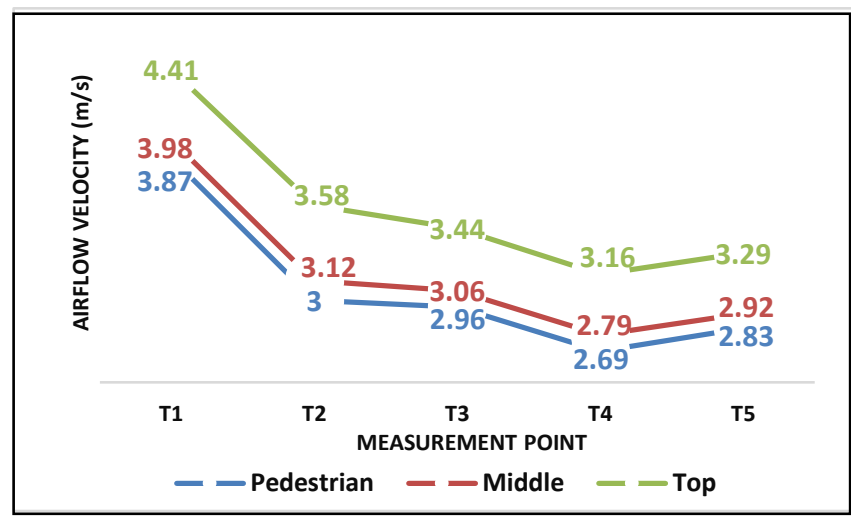

Fig. 19. Graph of airflow velocity reduction in scenario 1 (model 1B)

\section{$F$. Impact of $L / H$ aspect ratio towards changes in airflow velocity of scenario 2 and 3}

When compared to the schematics of $1 \mathrm{~A}$ and $1 \mathrm{~B}$, a different situation occurs over scenarios 2 (model 2B). Airflow velocity condition at the starting point (T1) is at lowest value. The value increases from $\mathrm{T} 1$ towards $\mathrm{T} 2$ and $\mathrm{T} 3$, before decreasing back at the fourth point (T4) and at the fifth poin (T5) experiences another increase (fig. 20). This situation is caused by an airflow leap resulting from the dimension of barrier buildings [14]. Boutet [10] and Latifa [11] state that airflow leaps due to a barrier takes time to return to its original position. In scenario 2, the airflow leap returns to its original position quicker than in scenario 3 because the barrier buildings are lower in height.

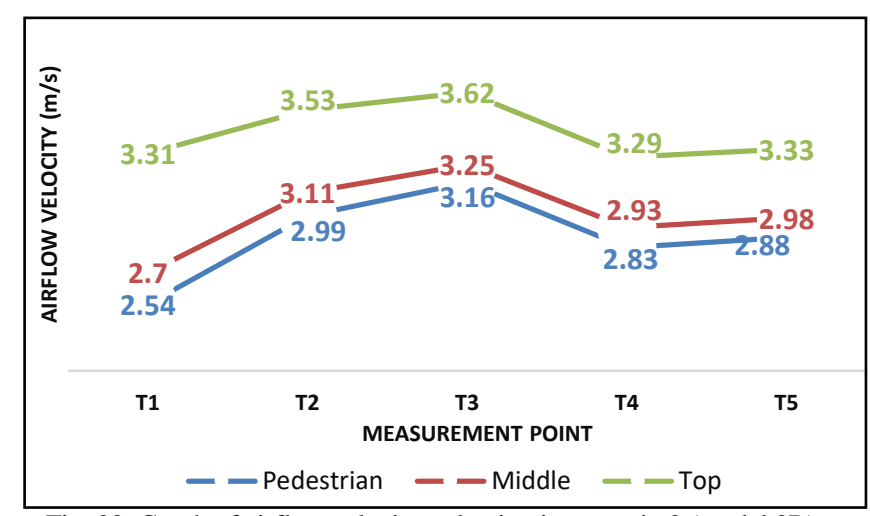

Fig. 20. Graph of airflow velocity reduction in scenario 2 (model 2B)

Another impacting factor is the height of the buildings of 15 floors present in model 2A. The presence of buildings changes the direction of airflow to descend into the pedestrian level and into the building canyon design and change the airflow velocity schematic of different model 2B (fig.21, 22). As Rajagopalan stated [15], canyon design conditions which contain buildings taller on one side than on its opposite, an advantage is resulted in west-east oriented canyon design, as the airflow which hits the buildings is redirected into the canyon design.

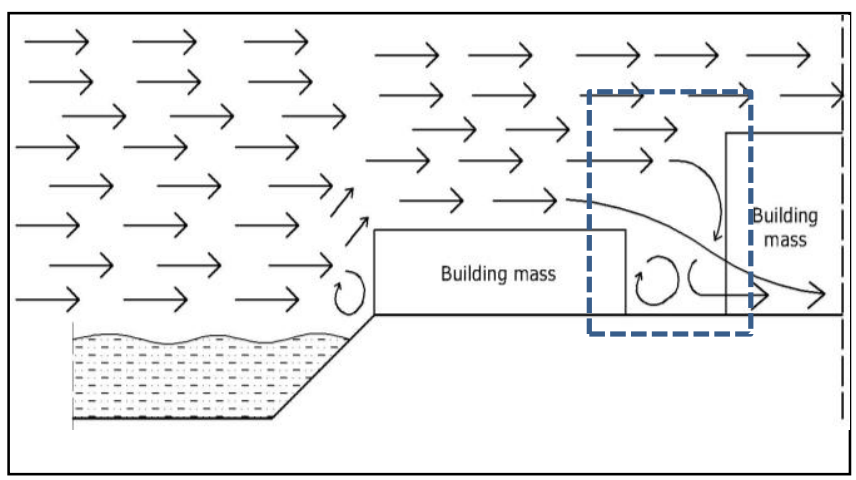

Fig. 21. Design model of urban canyon 2A produces variations of airflow velocity and direction in west-east oriented canyon design

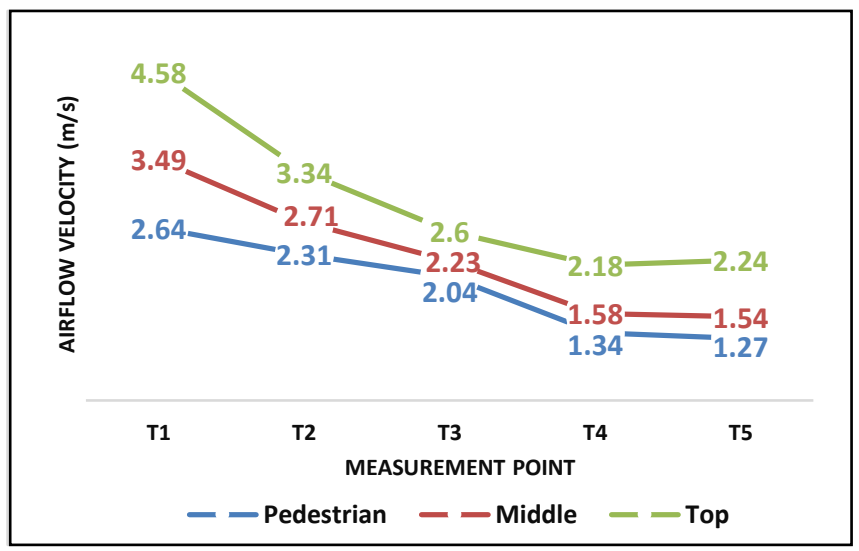

Fig. 22. Graph of airflow velocity reduction in scenario 2 (model 2A) 
In the next model, that is experimental scenario 3, a difference in the value of airflow velocity appears, but not in the airflow schematic. This condition is resulted from the contrasting heights of the canyon design buildings between models $3 \mathrm{~A}$ and $3 \mathrm{~B}$ (fig. 22 dan fig. 23).

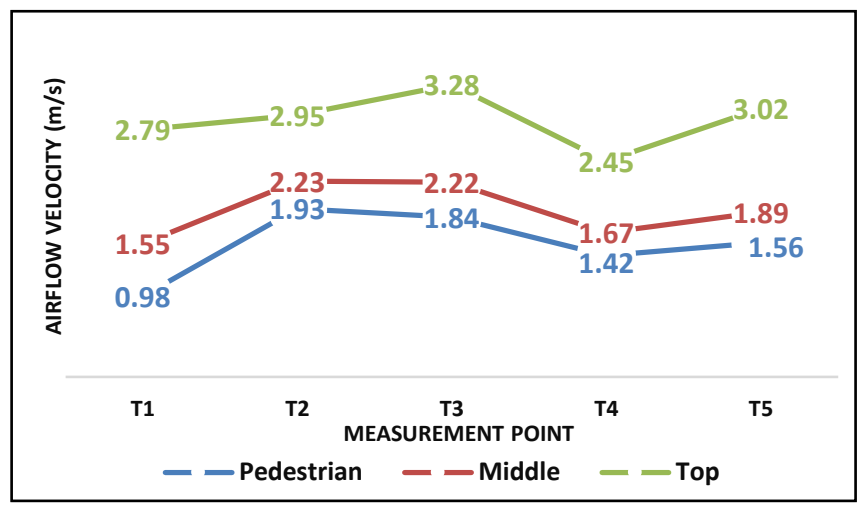

Fig. 23. Graph of airflow velocity reduction in scenario 3 (model 3A)

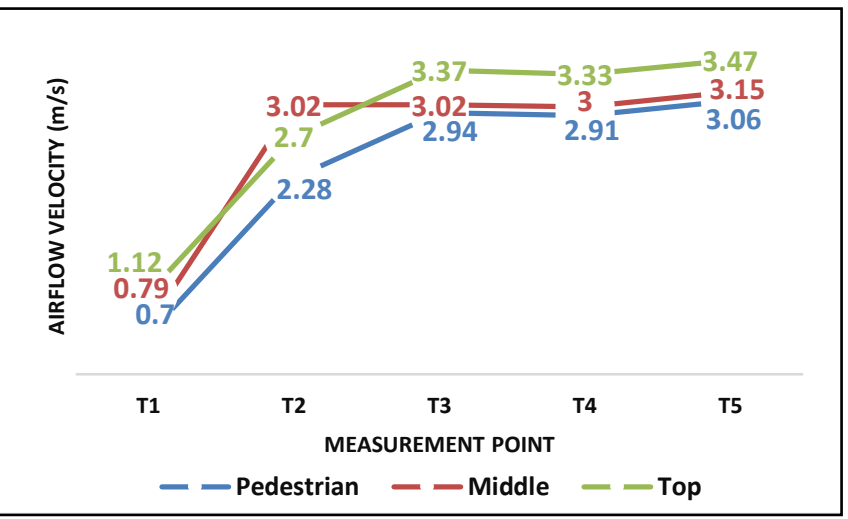

Fig. 24. Graph of airflow velocity reduction in scenario 3 (model 3B)

\section{CONCLUSION}

Deep canyon type with high H/W value in Selatpanjang City, either in field measurement or experimental results, produce lower air temperature condition when compared to shallow canyon. Canyon designs 1 and 2 with $\mathrm{H} / \mathrm{W}$ values of 2.14 and 1.72 , respectively, resulted in air temperatures of $33^{\circ} \mathrm{C}$ and $34^{\circ} \mathrm{C}$. While canyon designs 3 and 4 with $\mathrm{H} / \mathrm{W}$ values of 1.05 and 0.9 resulted in air temperatures $34.7^{\circ} \mathrm{C}$ and $35.4^{\circ} \mathrm{C}$, also respectively (fig. 25). In the experimental results, even in conditions without any barrier buildings, along with an increase in airflow velocity value up to $2.4 \mathrm{~m} / \mathrm{s}$, deep canyon design still has a lower air temperature value when compared to shallow canyon, albeit with a small air temperature difference value of $0.1{ }^{\circ} \mathrm{C}-0.4^{\circ} \mathrm{C}$ between scenarios 1 and 2 , and $0.7-0.95^{\circ} \mathrm{C}$ between scenarios 1 and 3 (fig. 26).

Meanwhile, long canyon design in Selatpanjang City resulted in lower airflow velocity changes at all levels when compared to short canyon. This can be seen in the comparison of changes in the airflow velocity values between model $1 \mathrm{~A}$ (short canyon) and 2A (long canyon) in conditions without barrier buildings. Model 1A resulted in a decrease in airflow velocity of $1.33 \mathrm{~m} / \mathrm{s}$ (pedestrian), $1.37 \mathrm{~m} / \mathrm{s}$ (middle), $1.46 \mathrm{~m} / \mathrm{s}$ (top), while model $1 \mathrm{~B}$ resulted in a decrease in airflow velocity of $0.87 \mathrm{~m} / \mathrm{s}$ (pedestrian), $0.78 \mathrm{~m} / \mathrm{s}$ (middle), $0.83 \mathrm{~m} / \mathrm{s}$ (top). From the above changes in airflow velocity, it can be concluded that long canyon has a stable decrease of airflow velocity which gives better cooling effect compared to short canyon. In the airflow schematic, the unobstructed canyon design has a regular airflow velocity reduction scheme at all altitude levels. While the design of the canyon in conditions affected by barrier buildings, airflow leaps occur due to the barrier buildings producing quiet areas at some points of observation, namely points $\mathrm{T} 1$ and

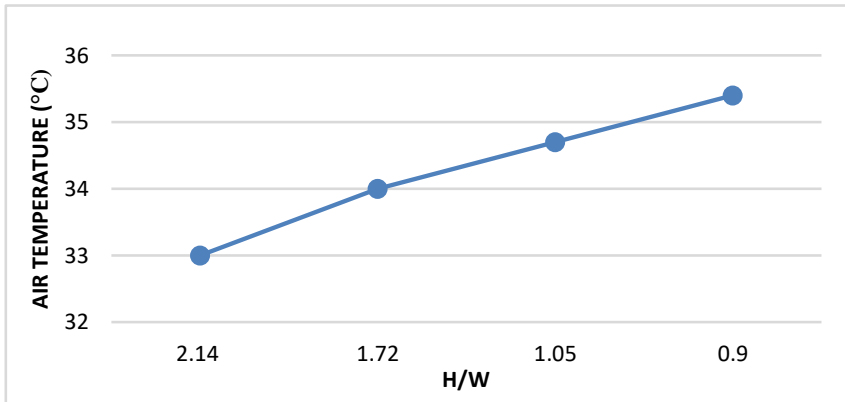

Fig. 25. Effect of $\mathrm{H} / \mathrm{W}$ on air temperature from field observation

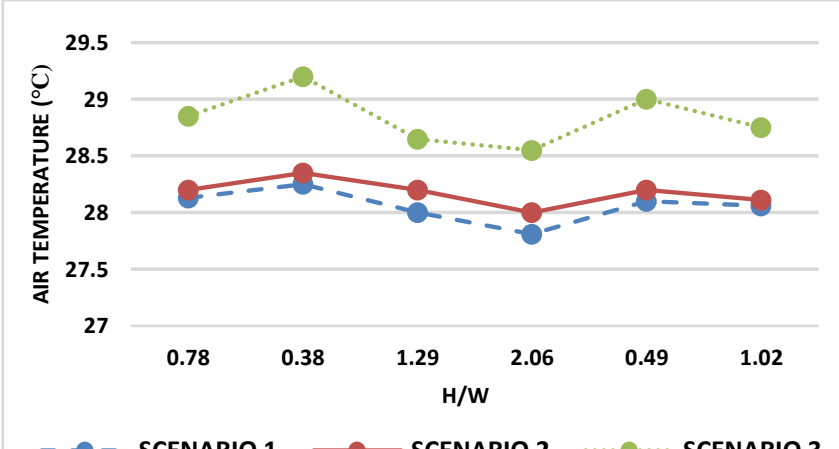

Fig. 26. Effect of $\mathrm{H} / \mathrm{W}$ on air temperature from field simulation

\section{REFERENCES}

[1] Cha, Jae-Gyu., Jung, Eung-ho., Ryu, Ji-Won., Kim, Dae-Wuk., (2007), Constructing a Green Network to Alleviate the Urban Heat-Island Phenomenon: Focusing on Daegu Metropolitan City in Korea, Real Corp 007 Proceddings, Tangungsband Vienna.

[2] Directorate General of Human Settlements, (2000), Waterfront Planning Regulation Policy.

[3] Oke, T.R., (1987), Boundary Layer Climates, London: Routledge

[4] Erell, E., Pearlmutter, D., Williamson, T.T.J., (2011), Urban microclimate: designing the spaces between buildings. Routledge

[5] Johansson, E., (2006), Influence of Urban Geometry on Outdoor Thermal Comfort in a Hot Dry Climate: A study in Fez, Morocco

[6] Bakarman, M.A., J.D. Chang., (2015), The Influence of Height/Width Ratio on Urban Heat Island in Hot-Arid Climates.

[7] Hang, Jia. Yugou Li. Dan Mats Sandberg. (2010), Wind conditions and ventilation in high-rise long street models. Building and Environment $45 ; 1353-1365$.

[8] Oke, T.R., (1981), Canyon geometry and the nocturnal urban heat island: Comparison of scale model and field observations.

[9] Aynsley, R.M., W. Melabourne dan Bj. Vickery, (1977), Architectural Aeorodynamics. Applied Science Publisher: London

[10] Boutet, T., (1987), Air Movement, Mc Graw Hill Co., New York.

[11] Latifa, N.L., (2015), Building Physics 1, Griya Kreasi, Cibubur, Jakarta.

[12] Vardoulakis, S., Fisher B.E.A., Perikleous K., Gonzalez-Flesca N., (2003), Modelling air quality in street canyons: a review.

[13] Soemarno, B.H.S., (2012), Pengendalian panas bangunan pada lingkungan permukiman kota berkepadatan tinggi yang tidak teratur di dataran rendah tropis lembab.

[14] Regional Regulation of Selatpanjang city Number 09 Year 2015 on "Built Areas for Maximum height for linear settlements"

[15] Rajagopalan, P., Kee Chuan Lim., Elmira Jamei., (2014), "Urban Heat Island and Wind Flow Characteristics of a Tropical City", School of Architecture and Built Environment, Deakin University, 1 Gheringhap Street, Geelong, Australia. 